\title{
Microbiologically induced concrete corrosion: A case study from a combined sewer network
}

Grengg, C. (1), Mittermayr, F. (2), Baldermann, A. (1), Böttcher, M. E. (3), Leis, A. (4), Koraimann, G. (5), Grunert, P. (6,7) \& Dietzel, M. (1)

(1) Institute of Applied Geosciences, Graz University of Technology, Rechbauerstraße 12, 8010, Graz, Austria

(2) Institute of Technology and Testing of Building Materials, Graz University of Technology, Inffeldgasse 24, 8010, Graz, Austria

(3) Leibniz Institute for Baltic Sea Research (IOW), Seestraße 15, D-18119 Warnemünde, Germany

(4) RESOURCES - Institute for Water, Energy and Sustainability, Joanneum Research, Elisabethstraße 18/2, 8010, Graz, Austria

(5) Institute of Molecular Biosciences, Graz Karl-Franzens University, Humboldstraße 50, 8010, Graz, Austria

(6) Institute of Earthsciences, Graz Karl-Franzens University, Heinrichstraße 26, 8010, Graz, Austria

(7) Department of Earth and Planetary Sciences, Rutgers University, 610 Taylor Road, Piscataway, NJ 08854-8066, United States of America

Keywords: Bacteria; X-Ray Diffraction; Durability; Sulfate Attack; Degradation 


\section{Abstract}

In this study, a strongly deteriorated concrete-based sewer system was investigated by using a multi proxy approach based on gaseous, hydro-geochemical, microbiological, mineralogical and mechanical analyses. Therefore, gas, liquid, and solid samples were taken throughout the entire sewer system. Long term measurements of gaseous hydrogen sulfide $\left(\mathrm{H}_{2} \mathrm{~S}\right)$ within the sewer atmosphere yielded concentrations up to $367 \mathrm{ppm}$. Interstitial fluids, extracted from deteriorated concrete by squeezing, contained sulfate $\left(\mathrm{SO}_{4}{ }^{2-}\right)$ concentrations of up to $104 \mathrm{~g} \mathrm{l}^{-1}$ at strong acidic conditions $(0.7>\mathrm{pH}>3.1)$ and are close to the saturation state of gypsum. This sulfuric acid attack is indicative for a wellestablished biofilm containing sulfide oxidizing bacteria (SOB), which was analyzed to consist mainly of Acidithiobacillus thiooxidans. The micro-structure of the attacked concrete displays a progressing alteration zone, which is caused by microbially induced concrete corrosion (MICC), with a suggested $\mathrm{pH}$ gradient from about 13 to $<1$, from the intact inner concrete zone to the outermost heavily deteriorated concrete. Calcium sulfate minerals such as gypsum $\left(\mathrm{CaSO}_{4} \cdot 2 \mathrm{H}_{2} \mathrm{O}\right)$, bassanite $\left(\mathrm{CaSO}_{4} \cdot 1 / 2 \mathrm{H}_{2} \mathrm{O}\right)$ and anhydrite $\left(\mathrm{CaSO}_{4}\right)$ are abundant in the altered concrete, which were formed from the dissolution of the cement phases and Ca-bearing aggregates. Remarkably high corrosion rates of different precast concrete manholes were quantified to reach values greater than $1 \mathrm{~cm} \mathrm{yr}^{-1}$, despite the fact that $\mathrm{C}_{3} \mathrm{~A}$-free cement, fly ash and a w/c of $\sim 0.35$ was used.

\section{Introduction}

Corrosion of concrete-based sewer systems due to the emission of hydrogen sulfide $\left(\mathrm{H}_{2} \mathrm{~S}\right)$ from wastewater is a worldwide occurring issue with great economical relevance. The so-called microbially induced concrete corrosion (MICC) [1][2] is considered to significantly reduce the lifespan of concrete structures, from expected 100 down to $30-50$ years, in extreme cases even down to 10 years [3]. The required remediation actions are often challenging as individual processes linked to MICC still remain uncertain and thus typically generate high costs. It has been estimated in 2002 that the United States need to spend about 390 billion dollars within the following 20 years in order to keep the existing wastewater infrastructure on life support [1]. In 1996, over 520 million dollars were spent solely in Los Angeles County for restorations of corroded sewer systems, which were directly assigned to MICC [4]. Besides economic aspects, $\mathrm{H}_{2} \mathrm{~S}$ and other volatile components such as ammonia $\left(\mathrm{NH}_{3}\right)$, which both 
are common byproducts of MICC, are extremely toxic even in low concentrations and can cause significant health related consequences [5][6]. Additionally, $\mathrm{H}_{2} \mathrm{~S}$ features an extremely low odor threshold of $0.0035 \mathrm{ppm}$, thus often being subject to community appeals due to emerging odor problems [7]. Although, the earliest studies of MICC date back to 1900 [8] the environmental controls, processes, and corrosion rates of MICC are still in debate.

The deterioration of concrete that is subjected to MICC is attributed to a chain of complex biotic and abiotic chemical reactions: (i) Sulfate-reducing bacteria (SRB), e.g. Desulfovibrio spp. and Desulfomaculum spp. [9][10], develop in the organic-rich wastewater and colonialize the adjacent sewer walls and sediment layers. The SRB colonize within an anaerobic biofilm, wherein organic matter breaks down and sulfate is progressively reduced to gaseous $\mathrm{H}_{2} \mathrm{~S}$ [11]. (ii) Accordingly, $\mathrm{H}_{2} \mathrm{~S}$ degases into the sewer atmosphere and subsequently accumulates in the pore space of the concrete via gaseous diffusion and subsequent absorption in the interstitial solution. Since concrete made with ordinary Portland cement (OPC) is a strongly alkaline media with an average $\mathrm{pH}$ value of $\sim 13.5$ in the pore solution [12], chemical acid-base reactions such as carbonation and in particular $\mathrm{H}_{2} \mathrm{~S}$ acidification successively cause the $\mathrm{pH}$ to drop. Starting from $\mathrm{pH} 9.5$, progressive colonization of the concrete walls with strains of sulfur-oxidizing bacteria (SOB) occurs. SOB use $\mathrm{H}_{2} \mathrm{~S}$ either directly [13] or via different key precursors, e.g. thiosulfate $\left(\mathrm{S}_{2} \mathrm{O}_{3}\right)$ or elemental sulfur $\left(\mathrm{S}^{0}\right)$ as an electron donor [14]. These reactions finally result in the formation of sulfuric acid $\left(\mathrm{H}_{2} \mathrm{SO}_{4}\right)$, which attacks the concrete and leads to a variety of dissolution processes, besides enhancing some neo-formation reactions of sulfate mineral phases within the cementitious matrix [15][16]. (iii) The dissociation of $\mathrm{H}_{2} \mathrm{SO}_{4}$ goes almost to completion and thus strongly reduces $\mathrm{pH}$ for stimulating the dissolution of silicate, hydroxide and carbonate minerals. In addition, by providing $\mathrm{SO}_{4}^{2-}$ the precipitation of sulfate minerals such as gypsum $\left(\mathrm{CaSO}_{4} \cdot 2 \mathrm{H}_{2} \mathrm{O}\right)$ and ettringite $\left((\mathrm{CaO})_{3} \cdot \mathrm{Al}_{2} \mathrm{O}_{3} \cdot\left(\mathrm{CaSO}_{4}\right)_{3} \cdot 32 \mathrm{H}_{2} \mathrm{O}\right)$ is promoted [17][18]. The formation of gypsum and ettringite is well known to cause intense microstructural damage by high crystallization pressures [19][20][21]. (iv) As the interstitial solution $\mathrm{pH}$ of the initially damaged concrete decreases progressively, different strains of bacteria colonize the pores of the concrete, with Acidithiobacillus thiooxidans being the most aggressive one [10]. 
Many laboratory studies were carried out focusing on the deterioration mechanisms related to MICC on different types of concrete [1][15][22][23][24], but so far field studies on MICC are rare [25]. Although, the results from laboratory experiments have been widely used to draw conclusions about MICC processes in natural environments, it is almost impossible to reproduce field environmental conditions of MICC in the lab. The aim of the present case study is to contribute to a deeper understanding of reaction paths, environmental controls, and corrosion rates related to MICC in a modern Austrian sewer system by introducing an advanced multi proxy approach that comprises gaseous, hydro-geochemical, bacteriological, mineralogical and mechanical analyses.

\section{Study site}

The investigated sewer system is located mainly in rural areas near the city of Graz in the southeastern part of Austria. It can be categorized as a combined sewer network [26], thus transporting the daily wastewater of around 13,000 citizen as well as the runoff from seasonal storm events. In recent years, the Austrian government demanded the fusion of smaller wastewater systems, which resulted in increasing amounts of longer intercepting sewers. Consistent with this concept, two new power mains were installed in 2004 in order to secure proper wastewater transport in local communities.

The newly built sewer system comprises a concrete storage basin (SB1), where the wastewater from the surrounding sewer channels is collected and pumped through the first power main (PM1), on average, every six hours. The PM1 is made of cast iron and polyethylene (PE) insets, with a sewer diameter of $200 \mathrm{~mm}$ and a sewer length of $4 \mathrm{~km}$. The adjoining PE gravity sewer (GS1), consists of around 50 concrete-based manholes (GS1-1 to GS1-50) and two small income pipes of residential areas, and is about $5 \mathrm{~km}$ in length. Subsequently, the wastewater is collected within a second storage basin (SB2) from which it is continuously pumped into another power main (PM2), with a length of 1.8 $\mathrm{km}$ and a $300 \mathrm{~mm}$ sewer diameter. The last part of the system holds another gravity sewer section (GS2), comprising 30 concrete-based manholes (GS2-1 to GS2-30), before the wastewater finally reaches the purification plant (Figure 1).

Both storage basins (SB1 and SB2) are made of concrete; however, no further investigations were conducted on this material since they showed no signs of visual damage. In contrary, some of the manholes in the gravity sewers were strongly deteriorated. In severe cases, the first few centimeters of 
the concrete revealed a mushy appearance and could be easily scraped off with bare hands. With increasing distance from the power main outlets, the intensity of concrete corrosion decreases, as seen in non-corroded manholes at the end of these sections (see Figure 1, A-C). The manholes are between $30 \mathrm{~cm}$ and $400 \mathrm{~cm}$ deep with great majority at an average depth of about 200-300 cm, and consist of precast concrete elements. The contract document specified precast elements with a compressive strength class of $\mathrm{C} 30 / 37, \mathrm{C}_{3} \mathrm{~A}$ free cement and a minimum water/cement $(\mathrm{w} / \mathrm{c})$ ratio of 0.45 to withstand severe aggressive environments (AS2 according to ÖNORM B 2503: Drain and sewer systems - Supplementary specifications for design, construction and testing). This classification corresponds to exposition class XA2 for chemical attack according to ÖNORM B 4710-1 (Concrete Part 1: Specification, production, use and verification of conformity. Rules for the implementation of EN 206-1 for normal and heavy concrete). According to the precast factory, implemented elements possessed a w/c ratio of $\sim 0.35$. CEM I $42.5 \mathrm{~N}\left(\mathrm{C}_{3} \mathrm{~A}\right.$-free) plus fly ash and $0.25 \mathrm{wt}$. \% of a PCE based superplasticizer, referred to cement content, were added to the concrete mixture.

The transported wastewater comprises mainly domestic wastewater, although one surface quarry and some minor commercial areas are also discharging into the system. Nevertheless, both the quality and chemical composition of the wastewater fulfills the statutory requirements for communal wastewater. Since the new power mains were installed, community complains of odor rose, which were caused by constant $\mathrm{H}_{2} \mathrm{~S}$ emission from the sewer system (Figure 1). As a first countermeasure, the manhole covers in populated areas were sealed, whereas sewer sections in sparsely populated regions remained perforated. Secondly, in order to prevent the establishment of anaerobic conditions (and subsequently $\mathrm{H}_{2} \mathrm{~S}$ accumulation) within the power mains, fresh air is pumped into the storage basins. Thirdly, a $15 \%$ iron(II)chloride $\left(\mathrm{FeCl}_{2}\right)$ solution is added regularly into the primary storage basin (since 2010) in order to reduce $\mathrm{H}_{2} \mathrm{~S}$ formation [20] by precipitation of sulfide ions as iron sulfides (e.g., pyrite, $\mathrm{FeS}_{2}$, and ironmonosulfide, $\mathrm{FeS}$ ).

\section{Materials and Methods}

In total 84 samples were collected for this study. This comprises solid and liquid samples (58 in total) from the corroded manholes of GS1 and GS2, as well as, liquid samples of SB1 and SB2 (5 in total). 
Gas measurements were conducted during the six sampling dates within representative manholes to value the concentrations of $\mathrm{H}_{2} \mathrm{~S}, \mathrm{CO}_{2}$, and $\mathrm{CH}_{4}$. In addition, long term gas observations were carried out in order to determine variations in the total $\mathrm{H}_{2} \mathrm{~S}$ volumes. Drill cores (21 in total), of $5 \mathrm{~cm}$ in diameter, were taken from heavily damaged and intact concrete to evaluate the concrete composition and corrosion rates. The residual thickness of the altered concrete liner was directly measured and compared with that of unaltered concrete (initially about $13 \mathrm{~cm}$ thick) to achieve corrosion rates in $\mathrm{cm}$ $\mathrm{yr}^{-1}$.

\subsection{Solids}

Deteriorated concrete mush from different sites was sampled and shoveled into plastic bags. The samples were dried at $40^{\circ} \mathrm{C}$ and subsequently grounded in a McCrone micronizing mill for 8 min, together with $10 \mathrm{wt}$ \% $\mathrm{ZnO}$ as internal standard. X-ray diffraction (XRD) patterns of randomly oriented preparations were recorded over the range of $4-85^{\circ} 2 \Theta$ with a step size of $0.008^{\circ} 2 \Theta$ and a count time of $40 \mathrm{~s} / \mathrm{step}$, using a PANalytical X'Pert PRO diffractometer. The diffractometer was equipped with a Co-tube (40 kV and $40 \mathrm{~mA}$ ), a spinner stage, $0.5^{\circ}$ divergence and antiscattering slits, and a Scientific X'Celerator detector. Mineral identification and quantification were carried out based on Rietveld refinement of powder XRD patterns using the PANalytical X'Pert HighScore software (version 2.2e) and pdf-2 database.

Extracted drill cores were used for compressive strength and gross density analysis. Therefore, $5 \mathrm{~cm}$ cylinders were cut (non-damaged part), subsequently dried, plane-parallel polished and tested, using a Toni Technik $300 \mathrm{kN}$ testing machine, according to Austrian guidelines ÖNORM EN 12504-1 (Testing concrete in structures - Part1: Cored specimens - Taking, examining and testing in compression).

In order to study mineral alterations and neo-formation features of the concrete, selected samples were analyzed with a Zeiss DSM 982 Gemini scanning electron microscope (SEM), operated at 5kV accelerating voltage, by mounting the samples on standard SEM stubs. Images of the sample material have been taken by using the DISS 5 software package (version 5.9.9.1). In addition, polished thin sections of various drill core samples were prepared to study the microstructural damage of the concrete by combined back-scattered electron imaging (BSE) and single spot analyses using an 
electron microprobe (EMPA) JEOL JXA-8200 Superprobe. Single spot analyses were made at an accelerating voltage of $15 \mathrm{kV}$ and $5 \mathrm{nA}$.

Damaged and unaltered concrete samples were analyzed for their sulfur (S) and total organic carbon (TOC, after acidification of samples to remove carbonate) contents using a Leco CS230 analyzer. The analytical error is $<5 \%$.

\subsection{Liquids}

On site, $\mathrm{pH}$ and electric conductivity (EC) were measured using a WTW Multi350i instrument equipped with a SenTix41 and a TetraCon325 electrode. $\mathrm{O}_{2}$ concentrations and redox potential were measured using a Hach LDO and a SenTix ORP electrode, respectively. For further hydrochemical analyses, wastewater samples were taken throughout the whole sewer system.

In the laboratory, the liquid samples were centrifuged using an Avanti ${ }^{\mathrm{TM}}{ }_{-} \mathrm{J}-25 \mathrm{I}$ centrifuge and subsequently filtered through $0.45 \mu \mathrm{m}$ membranes to remove suspended solids and most of the colloidal fraction. Afterwards, the carbonate alkalinity was measured by potentiometric titration with $0.005 \mathrm{M} \mathrm{HCl}$ (analytic error < 3\%). The major, minor, and trace element concentrations of filtered samples was measured by a Dionex ICS-3000 ion chromatograph (IC) and a PerkinElmer Optima 8300DV inductively coupled plasma optical emission spectrometer (ICP-OES; samples acidified with $\left.2 \% \mathrm{HNO}_{3}\right)$. The analytic error was determined to be $<3 \%$ for IC and $<6 \%$ for ICP-OES analyses. The dissolved organic carbon content (DOC) was analyzed using a Shimadzu TOC-VcPH+ASI-V Analyzer, with an analytical error below $5 \%$.

Dissolved $\mathrm{H}_{2} \mathrm{~S}$ was preserved with $5 \% \quad \mathrm{Zn}$ acetate solution and directly measured spectrophotrometrically at Leibniz Institute for Baltic Sea Research Warnemünde (IOW) according to Cline (1969) [27] using a Specord 40 (Analytic Jena) device with an analytical precision of $\pm 2 \%$ [28].

Hydrochemical modelling was carried out using the computer code PHREEQCi (version 3.1.5-9133). The minteq database was applied in order to calculate saturation indices of gypsum and anhydrite, whereas IInl database was used for bassanite [29].

A hydraulic press, in a modified setup of Tritthart [12], was used to extract the interstitial solutions of the concrete. Therefore, between 800 and $1100 \mathrm{~g}$ of the deteriorated concrete was filled into a steel 
cylinder of a specially adapted press and pressurized at $\sim 1200 \mathrm{kN} / \mathrm{mm}^{2}$. The squeezed solutions were sucked into a syringe. Conductivity and $\mathrm{pH}$ measurements were conducted instantly after sampling. The extracted pore solutions were then filtered through a $0.45 \mu \mathrm{m}$ membrane filter, and analyzed with the methods described above (see more details [30]).

\subsection{Microbiological Analyses}

Samples were analyzed to prove the existence of SOB in the sampled concrete. $1 \mathrm{~g}$ of deteriorated concrete was suspended in $1 \mathrm{ml} 0.9 \% \mathrm{NaCl}$ solution. $0.5 \mathrm{ml}$ was used to inoculate a $100 \mathrm{ml}$ Erlenmayer flask containing $20 \mathrm{ml}$ modified growth medium for the enrichment of Thiobacilli [31]. The medium contained $\left(\mathrm{NH}_{4}\right)_{2} \mathrm{SO}_{4}(0.4), \mathrm{KH}_{2} \mathrm{PO}_{4}(0.4), \mathrm{CaCl}_{2}$ (0.25), $\mathrm{FeSO}_{4}(0.01), \mathrm{MgSO}_{4}$ (0.5) and $\mathrm{Na}_{2} \mathrm{~S}_{2} \mathrm{O}_{3}$ (5) salts, reported in $\mathrm{g} \mathrm{I}^{-1}$, that were dissolved in distilled water. Bacteria, growing in this medium in a shaker-incubator at $25^{\circ} \mathrm{C}$ for five to seven days, were plated on solid medium with the same composition, but additionally containing $1.5 \mathrm{~g} \mathrm{I}^{-1}$ agar. Bacterial cells harvested by centrifugation from the liquid cultures or from colonies that were suspended in $50 \mu l$ water were used to extract DNA. Samples were subjected to heat induced lysis for $10 \mathrm{~min}$ at $98^{\circ} \mathrm{C}$. The released DNA was used for amplification of a 298 base pair 16S rDNA fragment using primers in conserved regions flanking two highly variable regions V5 and V6 [32] in standard PCR reactions using Phusion DNA polymerase (New England Biolabs). Forward primer: GATTAGATACCCTGGTAGTCCACGC; reverse primer: TCTCACGACACGAGCTGACGAC. The sequence of the gel purified DNA fragment was determined using both forward and reverse primers in separate sequencing reactions provided by the Eurofins Genomics (Germany) sequencing service. The resulting DNA sequence was searched in the $16 \mathrm{~S}$ rRNA database (Bacteria and Archaea) subset at the National Center for Biotechnology using BLASTN 2.2.30+.

\subsection{Gas Phase Analyses}

The concentrations of gaseous $\mathrm{H}_{2} \mathrm{~S}, \mathrm{CH}_{4}$, and $\mathrm{CO}_{2}$ within the sewer pipe atmosphere were measured periodically, using a Draeger 3000 gas monitor. Long-term gas observations coupled with temperature records were conducted to monitor the inhibitory effect of $\mathrm{FeCl}_{2}$ addition into the wastewater on 
gaseous $\mathrm{H}_{2} \mathrm{~S}$ emission. Therefore, several myDataSens $1000 \mathrm{H}_{2} \mathrm{~S}$ gas monitors were installed in consecutively positioned manholes, to monitor the $\mathrm{H}_{2} \mathrm{~S}$ concentrations over several weeks.

\section{Results}

\subsection{Wastewater chemistry - Atmospheric sewer composition}

Wastewater samples taken throughout the whole system showed a decrease in $\mathrm{pH}$ from $8.0 \pm 0.2$ within the storage basins (SB1 and SB2) down to $7.4 \pm 0.3$ within the sections of the gravity sewer (GS1 and GS2; Figure 1). Consistently, the redox potential values from $+51 \mathrm{mV}$ (SB1) and $+32 \mathrm{mV}$ (SB2) decreased down to $-248 \mathrm{mV}$ (GS1) and $-320 \mathrm{mV}$ (GS2), indicating the progressive evolution from oxidizing to strongly reducing conditions within the wastewater. Occurring re-oxidation could be quantified within GS1, where $\mathrm{O}_{2}$ concentrations increased from $1.4 \mathrm{mg} \mathrm{I}^{-1}$ in the first manhole (GS1-1) up to $4.3 \mathrm{mg} \mathrm{I}^{-1}$ within SB2. Interestingly, $\mathrm{O}_{2}$ concentrations at SB1 were extremely low, between 0.2 and $0.8 \mathrm{mg} \mathrm{l}^{-1}$. In SB1, sulfate concentrations from 64 to $115 \mathrm{mg} \mathrm{l}^{-1}$ were measured, which decreased down to $25 \pm 15 \mathrm{mg} \mathrm{I}^{-1}$ of $\mathrm{SO}_{4}{ }^{2-}$ in the first manholes of GS1 after the upper power main (PM1) of the system. In GS1 the $\mathrm{SO}_{4}{ }^{2-}$ concentration within the wastewater increased continuously with flow distance. Finally, in SB2, concentrations between 23 and $249 \mathrm{mg} \mathrm{l}^{-1}$ of $\mathrm{SO}_{4}{ }^{2-}$ were analyzed. After the second power main (PM2), low $\mathrm{SO}_{4}{ }^{2-}$ concentrations of $30 \pm 15 \mathrm{mg} \mathrm{l}^{-1}$ occurred again. Sulfide concentrations of $0.35 \mathrm{mg} \mathrm{I}^{-1}$ were measured within SB1, which decreased after the PM1 down to 0.06 $\mathrm{mg} \mathrm{l}^{-1}$. Individual concentrations of dissolved components in the wastewater are displayed in Table 1.

Data of long term gas measurements showed average concentrations of $6 \mathrm{ppm}$ of $\mathrm{H}_{2} \mathrm{~S}$, with large variations between 0.1 and $367 \mathrm{ppm}$, within the $4^{\text {th }}$ manhole of GS1 (GS1-4) during $\mathrm{FeCl}_{2}$ addition over a 6 week period (closed lid). Without $\mathrm{FeCl}_{2}$ addition, the $\mathrm{H}_{2} \mathrm{~S}$ concentrations at least doubled. Typical $\mathrm{H}_{2} \mathrm{~S}$ long term concentration, concurrent temperature variations and critical $\mathrm{H}_{2} \mathrm{~S}$ thresholds for the human beings are presented in Figure 2. Gas measurements, conducted during sampling within different manholes, displayed concentrations up to $84 \mathrm{ppm}$ of $\mathrm{H}_{2} \mathrm{~S}$ (open lids). With flow direction of the wastewater a decrease in gaseous $\mathrm{H}_{2} \mathrm{~S}$ concentrations was detected, resulting in manholes without any recognizable $\mathrm{H}_{2} \mathrm{~S}$ emission at the end of GS1 and GS2. Indeed, high $\mathrm{CO}_{2}$ concentrations of up to $2600 \mathrm{ppm}$ (typical atmospheric $\mathrm{CO}_{2}$ around $370 \mathrm{ppm}$ ) were measured throughout the whole 
system. Additionally, $\mathrm{CH}_{4}$ concentrations of up to $1760 \mathrm{ppm}$ were reached in the first few manholes after the two power mains.

\subsection{Sulfuric acid attack and concrete corrosion}

Drill cores, extracted from the most heavily corroded manholes in the upper sections of GS1 and GS2, revealed mean corrosion rates of $0.4 \mathrm{~cm} \mathrm{yr}^{-1}$ (Table 2). Significant higher maximum corrosion rates of up to $>1.0 \mathrm{~cm} \mathrm{yr}^{-1}$ were reached in certain strongly deteriorated manholes, e.g. GS2-1.

The intact precast concrete of drill cores, extracted from the manholes of GS1 and GS2, showed compressive strengths of $88 \pm 11 \mathrm{~N} / \mathrm{mm}^{3}$ and residual thickness of 4.0 to $12.5 \mathrm{~cm}$. Therefore, the loss of material within heavily corroded manholes could be determined with up to $9 \mathrm{~cm}$ within the last 9 years. Mineral compositions of intact concrete were quantified and subsequently compared to compositions of altered concrete. The siliceous compounds of the aggregates remained largely unaffected by corrosion, while the carbonatic aggregates were almost completely dissolved or transformed. Analogous, the latter is valid for the cementitious phases, mainly calcium-silicate-hydrate phases $(\mathrm{C}-\mathrm{S}-\mathrm{H})$ and portlandite $\left(\mathrm{Ca}(\mathrm{OH})_{2}\right)$. The alteration of Ca-bearing mineral phases yielded in the precipitation of large quantities of gypsum of up to 42 wt. \%. Additionally, significant amounts of anhydrite $\left(\mathrm{CaSO}_{4} ; 16 \pm 1\right.$ wt. \%) and bassanite $\left(\mathrm{CaSO}_{4} \cdot 0.5 \mathrm{H}_{2} \mathrm{O} ; 3 \pm 2\right.$ wt. \%) formed within the corrosion layer of the first two corroded manholes of GS1 (GS1-3 and GS1-4) and the first manhole of GS2 (GS2-1). The change in the quantitative, mineralogical composition of unaltered concrete into strongly deteriorated concrete layers is displayed in Table 3.

The amount of TOC in the deteriorated concrete ranged between 0.12 and 0.51 wt. \%, while TOC quantities between 0.09 and 0.25 wt. \% were analyzed for non-deteriorated, respectively.

Microprobe analyses clearly displayed proceeding transformation of the cementitious matrix into gypsum, as well as continuing dissolution and leaching of the cementitious phases. Carbonate aggregates were gradually dissolved and transformed into gypsum, whereas, within GS1-3, GS1-4 and GS2-1 additionally anhydrite and bassanite formation occurred. Secondary electron images (SEI) clearly showed gypsum formation within the deteriorated cementitious matrix (Figure 3). Residuals of the aggregates, mainly quartz, feldspar (plagioclase and K-feldspar) and mica (muscovite/biotite) as well as distinct Fe-bearing phases like ferrohornblende $\left(\left(\mathrm{Ca}_{2} \mathrm{Fe}_{5} \mathrm{Al}\left(\mathrm{SiAlO}_{22}\right)(\mathrm{OH})_{2}\right)\right.$ and ilmenite 
$\left(\mathrm{TiFeO}_{3}\right)$ remained unaltered. A sharp transition zone (width about $100 \mu \mathrm{m}$ ) can be seen between the initial pristine concrete and highly altered cementitious matrixes, displaying massive occurrences of gypsum, bassanite and anhydrite (Figure 4).

Interstitial solutions, extracted from the deteriorated concrete, showed extremely low pH values between 0.7 and 3.1, while concentrations of $\mathrm{SO}_{4}{ }^{2-}$ reached high values between 2 and $104 \mathrm{~g} \mathrm{I}^{-1}$. Additionally, high concentrations of $\mathrm{Ca}^{2+}\left(550 \pm 100 \mathrm{mg} \mathrm{l}^{-1}\right), \mathrm{Mg}^{2+}\left(52\right.$ to $\left.4321 \mathrm{mg} \mathrm{l}^{-1}\right)$ and $\mathrm{NH}_{4}^{+}(63$ to $2994 \mathrm{mg} \mathrm{I}^{-1}$ ) were measured. In general, a strong and positive correlation between a decrease in $\mathrm{pH}$ and elevated dissolved ion concentrations is evident. The Ca-concentration does not follow this trend, but displayed quite constant concentrations. All interstitial solutions were saturated with respect to gypsum ( $\left(\mathrm{I}_{\mathrm{Gp}}\right.$ between 0.02 and 0.41$)$ and anhydrite $\left(\mathrm{SI}_{\mathrm{Anh}}\right.$ between 0.01 and 0.43$)$ while being slightly under-saturated with respect to bassanite $\left(\mathrm{SI}_{\mathrm{BS}}\right.$ between -0.94 and -0.52). Typical enrichment trends in dissolved components, as well as saturation indices for relevant sulfate minerals are summarized in Table 4.

Bacteria, enriched from deteriorated concrete samples, were isolated and identified as SOB belonging to the species Acidithiobacillus thiooxidans. The sequenced $16 \mathrm{~S}$ rDNA fragment was $99.6 \%$ identical to the sequence of Acidithiobacillus thiooxidans ATCC 19377 (database entry NR_044920.1). A search against NCBI's (Nacional Center for Biotechnology Information) complete non-redundant nucleotide collection revealed several hits with $100 \%$ sequence identity to 16 sDNA fragments from uncultured bacteria (e.g. accession number KF845940) present in biofilms associated with concrete corrosion in the USA, for instance a $98.5 \%$ genetic conformity was determined for Acidithiobacillus ferrooxidans [33].

\section{Discussion}

The results obtained in the present case study verified that the underlying mechanisms of concrete corrosion are attributed to microbial induced concrete corrosion (MICC). Measured redox potentials down to $-320 \mathrm{mV}$ as well as low oxygen levels in the wastewater clearly indicated prevailing anaerobic conditions and associated bacterial activity within PM1 and PM2. There, anaerobic autotrophic organisms, mainly of the genus Desulfovibrus and Desulfobulbus, oxidized organic matter using sulfate as electron acceptor in the absence of oxygen and nitrate [3]. This process resulted in the 
formation of sulfide species, including $\mathrm{H}_{2} \mathrm{~S}$, at prevailing $\mathrm{pH}$ values between 7 and 8 . The sulfide production is accompanied by a significant decrease in the concentration of dissolved sulfate, from about 105 to $14 \mathrm{mg} \mathrm{l}^{-1}$, throughout the power mains. Subsequently, $\mathrm{H}_{2} \mathrm{~S}$ was liberated from the wastewater into the manholes atmospheres, where concentrations of up to $367 \mathrm{ppm} \mathrm{of} \mathrm{H}_{2} \mathrm{~S}$ were reached. $\mathrm{FeCl}_{2}$ addition has proven to trigger iron sulfide precipitation, e.g. $\mathrm{FeS}_{2}$ and $\mathrm{FeS}$, thus reducing $\mathrm{H}_{2} \mathrm{~S}$ concentrations down to an average value of $6 \mathrm{ppm}$. However, partial re-oxidation of metastable $\mathrm{FeS}$ into $\mathrm{SO}_{4}{ }^{2-}$ ions within GS1 due to re-aeration resulted in elevated $\mathrm{SO}_{4}{ }^{2-}$ concentrations of up to $247 \mathrm{mg} \mathrm{I}^{-1}$ within SB2. Subsequently, the sulfate ions are reduced within PM2 resulting in high sulfide production rates and consistently high $\mathrm{H}_{2} \mathrm{~S}$ emission within GS2-1. Concentrations of $\mathrm{CO}_{2}$ up to $2600 \mathrm{ppm}$ and $\mathrm{CH}_{4}$ up to $1760 \mathrm{ppm}$ were quantified in the sewer atmosphere. $\mathrm{CH}_{4}$ is a common byproduct of methanogenesis, which typically proceeds under extremely reducing conditions that are validated by redox potentials below $-200 \mathrm{mV}$ [26]. $\mathrm{CH}_{4}$ production is reported in areas within the power main, where sulfate depletion occurred, indicating complete reduction of $\mathrm{SO}_{4}{ }^{2-}$ into sulfide species within parts of PM1 and PM2 [34]. A schematic view of the main anaerobic microbial processes is given in Figure 5.

The liberation of volatile components from the wastewater is controlled by surrounding partial gas pressure, temperature and flow turbulences [5][13]. The latter seemed to engage in a central role concerning the degassing rapidity of the volatile components. Increased corrosion could be quantified in manholes of GS1 (GS1-3, GS1-4), where turns are enhancing flow turbulences and associated higher degassing rates of $\mathrm{H}_{2} \mathrm{~S}, \mathrm{CO}_{2}$ and $\mathrm{CH}_{4}$. Moreover, after PM2 the wastewater entered GS2 two meters above the channel bottom, creating a waterfall. With increasing flow direction, a significant increased decline in $\mathrm{H}_{2} \mathrm{~S}$ concentrations within the atmosphere of the concrete based manholes was measured. Simultaneously, the highest corrosion rates of about $1 \mathrm{~cm} \mathrm{yr}^{-1}$ were measured in the first manhole of GS2 (GS2-1). Hence, in GS2 the intensities of cement corrosion decreased much faster with flow distance, compared to GS1 (Figure 6).

After entering the sewer atmosphere within the manholes, $\mathrm{H}_{2} \mathrm{~S}$ was absorbed into the interstitial solutions of the outer layer of the concrete walls, where it oxidized through complex reaction paths [22][11], with $\mathrm{H}_{2} \mathrm{SO}_{4}$ being the final product. It is suggested that the uptake and transformation of gaseous $\mathrm{H}_{2} \mathrm{~S}$ into $\mathrm{H}_{2} \mathrm{SO}_{4}$ is more efficient in manholes with sealed covers, since ventilation out of the manhole atmosphere is hampered and $100 \%$ water saturation within the pore structure of the concrete 
is reached, creating an environment similar to a bioreactor. Quantification of how much exactly sealed covers attribute towards intensifying corrosion is difficult, since all those strongly deteriorated manholes are situated within the first part of GS1 and GS2, where simultaneously most intensive degassing occurred. However, no visible corrosion could be seen within the first two manholes of GS1 (GS1-1, GS1-2), which are coated with perforated covers, whereas the following strongly deteriorated manholes, (GS1-3 and following), matched those with sealed covers. Additionally, the straight course within this first 50 meters of GS1 promoted a calm wastewater flow with minor flow turbulences and consequential low degasification rates. During the early stages of the MICC attack carbonation due to the interaction between $\mathrm{CO}_{2}$, condensed water, the calcium hydrate phases $(\mathrm{C}-\mathrm{H})$ and $\mathrm{C}-\mathrm{S}-\mathrm{H}$ phases of the cementitious matrix took place. Additionally, abiotic oxidation of $\mathrm{H}_{2} \mathrm{~S}$ occurred, producing thiosulfuric and polythionic acids [14]. Both processes reduced the $\mathrm{pH}$ from initially $\sim 13$ down to $\sim 9.5$. Below the latter $\mathrm{pH}$, progressive colonization of aerobic heterotrophic bacteria results in biotic $\mathrm{H}_{2} \mathrm{SO}_{4}$ production. Through ongoing decrease of $\mathrm{pH}$ different strains of neutrophile SOB colonized the pore system. Starting from $\mathrm{pH} 5$, acidophil bacteria appeared. The bacteria extracted from the deteriorated concrete were identified as Acidithiobacillus thiooxidans, which thrive until $\mathrm{pH} 0.2$, if sulfate concentrations exceed about $74 \mathrm{~g} \mathrm{I}^{-1}$ [35]. In our pore fluids the sulfate concentrations were up to $104 \mathrm{~g}$ $\mathrm{I}^{-1}$.

It is likely that the bacteria Acidithiobacillus ferrooxidans play a central role in intensifying the corrosion rate of concrete in the present case study. These sulfur-oxidizing chemolithrophs have the ability to use ferric iron as an electron acceptor, if oxygen supply is limited. This ability potentially favors the production of $\mathrm{H}_{2} \mathrm{SO}_{4}$ in deeper, anoxic layers of the concrete, thereby accelerating the deterioration of the cementitious phases [36]. Huge amounts of dissolved iron of up to $15.6 \mathrm{~g} \mathrm{I}^{-1}$ were determined within the interstitial solution of deteriorated concrete (Table 4). The metabolism of Acidithiobacillus thiooxidans and, most likely Acidithiobacillus ferrooxidans, press ahead with the $\mathrm{H}_{2} \mathrm{SO}_{4}$ production and adherent concrete deterioration. According to Islander et. al. 1991 [14], only within this last stage of MICC, where acidophil bacteria are adopting the pore volume at $\mathrm{pH}$ below 5 , intense concrete breakdown takes place. Considering higher corrosion rates as MICC progresses, it can be taken for granted that during the last years the corrosion rates within the system significantly exceeded the measured average rates of up to $1 \mathrm{~cm} \mathrm{yr}^{-1}$. This is due to the fact that the measured rates reflect the mean annual loss of concrete wall material since the installation of the sewer system in 2004, whereas 
concrete alteration in the first years of service is considered low (Table 2). Measured TOC concentrations within the concrete of the initial precast elements confirm the application of superplasticizers, i.e. polycarbooxylate ether based superplasticizer (PCEs), which might promote the development of SOB by providing an additional carbon source for bacterial metabolism, beside of $\mathrm{CO}_{2}$.

The produced $\mathrm{H}_{2} \mathrm{SO}_{4}$ triggered the dissolution of the cementitious matrix and carbonatic aggregates, as well as the neo-formation of gypsum, bassanite and anhydrite. In general, the degradation of the concrete can be assigned to coupled chemical reactions, as well as mechanical and microstructural processes (Figure 6). Quantitative XRD analysis showed the gradual reduction of the C-S-H phases (amorphous content), portlandite and carbonates. The dissolution of these phases resulted in high concentrations of total dissolved solids and associated oversaturation of the interstitial solutions towards calcium sulfate minerals, thus triggering massive neo-formation of gypsum of up to $42 \mathrm{wt}$ \%. Due to proceeding dissolution of the supporting cementitious matrix, silica aggregates break out, which caused a decrease in their abundances, although virtually not affected by MICC. Expected ettringite formation lacked due to its high solubility at the present low pH values and the fact that $\mathrm{C}_{3} \mathrm{~A}-$ reduced concrete was used in the concrete mixture. Bassanite and anhydrite formation within the most heavily corroded manholes (GS1-3, GS1-4 and GS2-1) could be explained by wetting and drying cycles and subsequent variable $\mathrm{SO}_{4}{ }^{2-}$ and $\mathrm{H}_{2} \mathrm{O}$ activities within the interstitial solutions of the concrete. According to Lawrence et. al. 1967 [37], transformation of gypsum into anhydrite occurs within a 4 molar $\mathrm{H}_{2} \mathrm{SO}_{4}$ solution at $1 \mathrm{~atm}$ pressure and $23^{\circ} \mathrm{C}$. Microprobe analysis support the concept of gradual depletion of the C-S-H phases within the cementitious matrix, adherent dissolution of portlandite and calcite, as well as massive Ca-mineral neo-formation due to propagating corrosion (Figure 4). Moreover, progressing sulfate ion diffusion into the initially damaged concrete matrix is accompanied with a depletion of $\mathrm{Si}$ - and $\mathrm{Mg}$-bearing cementitious phases, whereas $\mathrm{Ca}$ concentrations remained largely constant due to precipitation as (hydrated) Ca-sulfates. The mobilization and uptake of $\mathrm{SO}_{4}{ }^{2-}$ ions proceeded along cracks and grain boundaries between the aggregates and the cement matrix, before propagating throughout the whole matrix.

Possible remediation strategies for the present case system are referred to the application of calcium aluminate cement $(C A C)$ based concrete, as they show better performances in systems exposed to MICC, compared to OPC concrete [38][39][40]. Here, the composition of the applied cement plays a 
major role concerning the establishment of biofilms within concrete pore volumes. CAC reveals inhibitory effects on the activity of the neutrophile bacteria since $\mathrm{Al}$ is known to have bacteriostatic characteristics [41]. Additionally, the hydrated alumina phases react with the $\mathrm{H}_{2} \mathrm{SO}_{4}$, to form an alumina gel layer, which significantly decreases the porosity and permeability and hence the diffusion rates in particular within the concrete surface layers. Since the alumina gel layer forms instantaneously, significant lower $\mathrm{H}_{2} \mathrm{~S}$ diffusion rates, as well as lower oxygen penetration depths could be achieved, thereby limiting biofilm adhesion [40]. Furthermore, the higher acid neutralization capacity of $\mathrm{Al}(\mathrm{OH})_{3}$ compared to Ca-hydroxide/carbonate minerals decelerates the $\mathrm{pH}$ decrease of the concrete within corrosive environments. In this context, it is crucial to adapt the Austrian standards for sanitary engineering (e.g. ÖNORM B 2503 in Austria), which currently neither value critical $\mathrm{H}_{2} \mathrm{~S}_{\text {gas }}$ levels for constructive materials, nor other potentially relevant gaseous components, such as $\mathrm{CO}_{2}$ and $\mathrm{NH}_{3}$. Additionally, suggested $\mathrm{C}_{3} \mathrm{~A}$-free concrete contains higher $\mathrm{Fe}_{2} \mathrm{O}_{3}$ contents, which might favor the development of Acidithiobacillus ferrooxidans, thus increasing biotic $\mathrm{H}_{2} \mathrm{SO}_{4}$ production.

\section{Summary and Conclusion}

In the present study, a multi proxy approach, including mineralogical, mechanical, chemical, and biological analyses, was used as a highly powerful tool to investigate the complex reaction mechanisms and controlling environmental parameters for progressing MICC. The deterioration of concrete in the studied Austrian sewer system was accordingly identified to be attributed to bacteriogenically induced sulfuric acid attack, associated with the formation and degassing of high quantities of $\mathrm{H}_{2} \mathrm{~S}$. Long retention times of the wastewater within the power mains combined with sealed manhole covers and low discharge rates created "bioreactor conditions", which resulted in high microbial activity, abundant sulfate reduction, subsequently $\mathrm{H}_{2} \mathrm{~S}$ degassing and $\mathrm{H}_{2} \mathrm{SO}_{4}$ production. $\mathrm{H}_{2} \mathrm{SO}_{4}$ accumulation in the interstitial solutions of the concrete resulted in $\mathrm{pH}$ values between 0.7 and 3.1. This extremely aggressive (micro)environment enhanced the dissolution of the cement matrix and in particular the breakdown of non-siliceous aggregates as well as the neo-formation of potentially expandable alteration products, i.e. gypsum, bassanite and anhydrite. In the present case, the expected ettringite formation lacked due to very low $\mathrm{pH}$ values and the application of $\mathrm{C}_{3} \mathrm{~A}$-free concrete used for the concrete mixture. High concrete corrosion rates exceeding $1 \mathrm{~cm} \mathrm{y}^{-1}$ were obtained, which caused large parts of the present sewer system to be strongly deteriorated after only 9 
years of usage, although highly sulfate resistant concrete plus fly ash (w/c $0.35 ; \mathrm{C}_{3} \mathrm{~A}$-free cement) was applied.

\section{Acknowledgements}

The authors gratefully thank the Graz University of Technology (Austria) scientific grant program for financial support, as well as the scientific input of Josef Tritthart. Additionally, special thanks to Peter Rappold and the Department of Water Resources Management, Styria, as well as to Heinz Lackner and the Department of Energy, Residential Constructions and Technology, Styria, for their financial support. Mineralogical and chemical analyses were carried out at the NAWI Graz Central Lab for Water, Minerals and Rocks. Bacterial isolation and identification were conducted with the expert technical assistance of Karin Bischof at the Institute of Molecular Biosciences, University of Graz (Austria). Jason Prabitz of Kirchdorfer Fertigteilholding GmbH and Johannes Kaissl of VTA GmbH are acknowledged for their technical support. 


\section{References}

[1] M.G.D. Gutiérrez-Padilla, A. Bielefeldt, S. Ovtchinnikov, M. Hernandez, J. Silverstein, Biogenic sulfuric acid attack on different types of commercially produced concrete sewer pipes, Cem. Concr. Res. 40 (2010) 293-301. doi:10.1016/j.cemconres.2009.10.002.

[2] M. O'Connell, C. McNally, M.G. Richardson, Biochemical attack on concrete in wastewater applications: A state of the art review, Cem. Concr. Compos. 32 (2010) 479-485. doi:10.1016/j.cemconcomp.2010.05.001.

[3] H.S. Jensen, PhD thesis; Hydrogen sulfide induced concrete corrosion of sewer networks, Aalborg University, 2009.

[4] A.P. Joseph, J. Keller, H. Bustamante, P.L. Bond, Surface neutralization and H(2)S oxidation at early stages of sewer corrosion: influence of temperature, relative humidity and $\mathrm{H}(2) \mathrm{S}$ concentration., Water Res. 46 (2012) 4235-45. doi:10.1016/j.watres.2012.05.011.

[5] E. Saracevic, PhD thesis; Zur Kenntnis der Schwefelwasserstoffbildung und -vermeidung in Abwasserdruckleitungen, TU Wien, 2008.

[6] World Health Organisation, Hydrogen Sulfide, in: Air Qual. Guidel. Eur., Copenhagen, 2000: p. 7. http://www.euro.who.int/_data/assets/pdf_file/0005/74732/E71922.pdf.

[7] WHO, Air Quality Guidelines, 40 (2001) 9823. doi:10.1002/15213773(20010316)40:6<9823::AID-ANIE9823>3.3.CO;2-C.

[8] W.M. Olmstead, H. Hamlin, Converting portions of the Los Angeles outfall sewer into a septic tank., Eng. News. (1900) 971-980.

[9] H.T. Dinh, J. Kuever, M. Mußmann, A.W. Hassel, Iron corrosion by novel anaerobic microorganisms, Nature. (2004) 829-832.

doi:10.1038/nature02349.1.2.3.4.5.6.7.8.9.10.Wilson.

[10] T. Hvitved-Jacobsen, J. Vollertsen, C. Yongsiri, A.H. Nielsen, Sewer microbial processes, emissions and impacts, in: Sewer Process. Networks, Paris, 2002: p. 13.

[11] M. Alexander, A. Bertron, N. De Belie, Performance of Cement-Based Materials in Aggressive Aqueous Environments, 1st ed., Springer, Ghent, 2013. doi:10.1007/978-94-007-5413-3.

[12] J. Tritthart, Chloride binding in cement I. Investigations to determine the composition of porewater in hardened cement., Cem. Conrete Res. 19 (1989) 586-94.

[13] H.S. Jensen, P.N.L. Lens, J.L. Nielsen, K. Bester, A.H. Nielsen, T. Hvitved-Jacobsen, et al., Growth kinetics of hydrogen sulfide oxidizing bacteria in corroded concrete from sewers., J. Hazard. Mater. 189 (2011) 685-91. doi:10.1016/j.jhazmat.2011.03.005.

[14] B.R.L. Islander, J.S. Devinny, A. Member, F. Mansfeld, A. Postyn, H. Shih, Microbial ecology of crown corrosion in sewers, J. Environ. Eng. 117 (1992) 751-770.

[15] A.H. Nielsen, J. Vollertsen, H.S. Jensen, T. Wium-Andersen, T. Hvitved-Jacobsen, Influence of pipe material and surfaces on sulfide related odor and corrosion in sewers., Water Res. 42 (2008) 4206-14. doi:10.1016/j.watres.2008.07.013.

[16] A. Yousefi, A. Allahverdi, P. Hejazi, Accelerated biodegradation of cured cement paste by Thiobacillus species under simulation condition, Int. Biodeterior. Biodegradation. 86 (2014) 317-326. doi:10.1016/j.ibiod.2013.10.008. 
[17] L. Zhang, P. De Schryver, B. De Gusseme, W. De Muynck, N. Boon, W. Verstraete, Chemical and biological technologies for hydrogen sulfide emission control in sewer systems: a review., Water Res. 42 (2008) 1-12. doi:10.1016/j.watres.2007.07.013.

[18] S. Soleimani, O.B. Isgor, B. Ormeci, Resistance of biofilm-covered mortars to microbiologically influenced deterioration simulated by sulfuric acid exposure, Cem. Concr. Res. 53 (2013) 229238. doi:10.1016/j.cemconres.2013.06.016.

[19] F. Mittermayr, M. Rezvani, A. Baldermann, S. Hainer, P. Breitenbücher, J. Juhart, et al., Sulfate resistance of cement-reduced eco-friendly concretes, Cem. Concr. Compos. 55 (2015) 364373. doi:10.1016/j.cemconcomp.2014.09.020.

[20] G. Jiang, E. Wightman, B.C. Donose, Z. Yuan, P.L. Bond, J. Keller, The role of iron in sulfide induced corrosion of sewer concrete., Water Res. 49 (2014) 166-74. doi:10.1016/j.watres.2013.11.007.

[21] D.J. Roberts, D. Nica, G. Zuo, J.. Davis, Quantifying microbially induced deterioration of concrete: initial studies, Int. Biodeterior. Biodegradation. 49 (2002) 227-234. doi:10.1016/S0964-8305(02)00049-5.

[22] N. De Belie, J. Monteny, a. Beeldens, E. Vincke, D. Van Gemert, W. Verstraete, Experimental research and prediction of the effect of chemical and biogenic sulfuric acid on different types of commercially produced concrete sewer pipes, Cem. Concr. Res. 34 (2004) 2223-2236. doi:10.1016/j.cemconres.2004.02.015.

[23] J. Herisson, E.D. van Hullebusch, M. Moletta-Denat, P. Taquet, T. Chaussadent, Toward an accelerated biodeterioration test to understand the behavior of Portland and calcium aluminate cementitious materials in sewer networks, Int. Biodeterior. Biodegradation. 84 (2013) 236-243. doi:10.1016/j.ibiod.2012.03.007.

[24] A. Eštokov, V.O. Harbuláková, A. Luptáková, N. Števulová, Study of the Deterioration of Concrete Influenced by Biogenic Sulphate Attack, Procedia Eng. 42 (2012) 1731-1738. doi:10.1016/j.proeng.2012.07.566.

[25] A.H. Nielsen, J. Vollertsen, H.S. Jensen, H.I. Madsen, T. Hvitved-Jacobsen, Aerobic and Anaerobic Transformations of Sulfide in a Sewer System - Field Study and Model Simulations, Proc. Water Environ. Fed. 2006 (2006) 3654-3670. doi:10.2175/193864706783751447.

[26] T. Hvitved-Jacobsen, J. Vollertsen, A.H. Nielsen, Sewer Processes - Microbial and Chemical Process Engineering of Sewer Networks, Second Edi, CRC Press, London, 2013.

[27] D. Cline, J, Spectrophotometric determination of hydrogen sulfide in natural waters., Limnol. Oceanogr. 14 (1969) 454-458.

[28] N. Kowalski, O. Dellwig, M. Beck, M. Grunwald, C.-D. Dürselen, T.H. Badewien, et al., A comparative study of manganese dynamics in the water column and sediments of intertidal systems of the North Sea, Estuar. Coast. Shelf Sci. 100 (2012) 3-17. doi:10.1016/j.ecss.2011.03.011.

[29] D.L. Parkhurst, C.A.J. Apello, User's guide to PHREEQC (V2), (1999) 312.

[30] F. Mittermayr, A. Baldermann, C. Kurta, T. Rinder, D. Klammer, A. Leis, et al., Evaporation - a key mechanism for the thaumasite form of sulfate attack, Cem. Concr. Res. 49 (2013) 55-64. doi:10.1016/j.cemconres.2013.03.003.

[31] R.L. Starkley, Isolation of some bacteria which oxidize thiosulfate., Soil Sci. 39 (1935) 197220. 
[32] S. Chakravorty, D. Helb, M. Burday, N. Connell, D. Alland, A detailed analysis of 16 S ribosomal RNA gene segments for the diagnosis of pathogenic bacteria., J. Microbiol. Methods. 69 (2007) 330-9.

[33] A.L. Ling, C.E. Robertson, N.R. Pace, M.T. Hernandez, Microbial and Chemical Characterization of Concrete Corrosion Biofilms of Wastewater Infrastructure in Ten Cities, (Unpublished). (n.d.).

[34] T.E. Cappenberg, Interrelations between sulfate-reducing and methane-producing bacteria in bottom deposits of a fresh-water lake., J. Microbiol. 40 (1974) 285-95.

[35] E.Y. Lee, N.Y. Lee, K.-S. Cho, H.W. Ryu, Removal of hydrogen sulfide by sulfate-resistant Acidithiobacillus thiooxidans AZ11., J. Biosci. Bioeng. 101 (2006) 309-14. doi:10.1263/jbb.101.309.

[36] D.E. Rawlings, D. Dew, C. Plessis, Biomineralization of metal-containing ores and concentrates, 7799 (2002) 4-5.

[37] L.A. Hardie, The gypsum-anhydrite equilibrium at one atmosphere pressure., Am. Mineral. 52 (1967).

[38] J. Herisson, E.D. van Hullebusch, M. Moletta-Denat, P. Taquet, T. Chaussadent, Toward an accelerated biodeterioration test to understand the behavior of Portland and calcium aluminate cementitious materials in sewer networks, Int. Biodeterior. Biodegradation. 84 (2013) 236-243. doi:10.1016/j.ibiod.2012.03.007.

[39] J. Herisson, M. Guéguen-Minerbe, E.D. van Hullebusch, T. Chaussadent, Behaviour of different cementitious material formulations in sewer networks., Water Sci. Technol. 69 (2014) 1502-8. doi:10.2166/wst.2014.009.

[40] J. Herisson, M. Gueguen-Minerbe, E.D. Van Hullebusch, T. Chaussadent, Biogenic corrosion mechanism: Study of parameters explaining calcium aluminate cement durability., in: Calcium Aluminates, Balkema, 2014: pp. 645-58.

[41] A.M. Goyns, M. Alexander, Performance of various concretes in the Virginia experimental sewer over 20 years., in: Calcium Aluminates, Balkema, 2014: pp. 573-84. 
Figure Captions:

Figure 1:

Schematic map of the Austrian sewer network near Graz. The intensity of concrete corrosion is indicated by the orange (intense deterioration) and yellow colour (less deterioration). Note that the highest corrosion level occurs within the sealed manhole covers. Intensive degassing of $\mathrm{H}_{2} \mathrm{~S}, \mathrm{CO}_{2}$, $\mathrm{CH}_{4}$, and $\mathrm{NH}_{3}$ is indicated with solid arrows within the upper parts of the system and the partly perforated manhole covers, while lower emission is indicated with doted arrows. Fresh air and iron-salt $\left(\mathrm{FeCl}_{2}\right)$ are constantly added to the storage basin 1 (SB1) to limit the $\mathrm{H}_{2} \mathrm{~S}$ concentrations in the atmosphere of the selected manholes by iron sulfide formation. On the right, inserted images $A$ and $B$ show examples of strongly deteriorated concrete of manholes within the upper parts of the gravity sewer sections, while $\mathrm{C}$ represents less degraded concrete of manholes within the middle parts of the system.

Figure 2:

Typical evolution of concentrations of gaseous $\mathrm{H}_{2} \mathrm{~S}$ within the $4^{\text {th }}$ manhole (GS-1-4) of GS1 (grey line). Internal manhole temperature is displayed in green colour. Red stars (A-E) mark important $\mathrm{H}_{2} \mathrm{~S}$ thresholds for human beings, such as odor threshold (A), eye irritation and headache (B), severe damages of eyes and respiratory systems (C), emerging odourless for human beings (D) and possible death $(\mathrm{E})[7]$.

Figure 3:

SE-images showing neo-formed gypsum (Gp) crystals due to propagating MICC, as well as amorphous silica (amp. Si) and relicts of mica such as muscovite (Ms).

Figure 4: 
BSE images of partly altered concrete. Top left (A) shows the sharp transition zone between strongly deteriorated concrete with abundant gypsum (Gp) on the left side and less altered concrete on the right side (red line). Top right (B) displays the gradual replacement of calcite (Cal) by gypsum (Gp). Bottom left $(\mathrm{C})$ shows a corrosion front progressing from the right to the left side, causing dissolution of calcite and precipitation of gypsum, anhydrite (Anh) and bassanite (Bs), while grains of the additives like quartz $(\mathrm{Qz})$, ilmenite $(\mathrm{Ilm})$, biotite $(\mathrm{Bt})$ and Albite $(\mathrm{Ab})$ remain largely unaffected. Bottom left $(\mathrm{D})$ displays an enlarged view of a calcite grain, which is transformed into anhydrite and bassanite. Gypsum occurs within the corroded matrix.

Figure 5:

Schematic view of the 3 microbial processes occurring under anaerobic conditions [20]. Initial transformation from complex organic molecules (COM) into low molecular organics (LMO) takes place through a series of reduction and oxidation processes. LMO are consumed by sulfate-reducing bacteria as well as methane-producing bacteria resulting in the formation of sulfide species, beside methane $\left(\mathrm{CH}_{4}\right)$ and $\mathrm{CO}_{2}$ production. Note that each individual process is limited to a distinct redox potential.

Figure 6:

Change in the quantitative, mineralogical composition of unaltered (grey) versus heavily damaged concrete (green), related to MICC. The concrete corrosion rate with flow distance within GS1 and GS2 is reported on top of the figure. Note the significantly highly localized concrete damage in GS2. *Ongoing dissolution of the supporting cementitious matrix is causing dilution of siliceous compounds such as quartz $(\mathrm{Qz})$, plagioclase $(\mathrm{PI})$, K-feldspar (Kfs), muscovite $(\mathrm{Ms})$ and hornblende $(\mathrm{Hb})$. Decrease of carbonatic and cementitious phases like calcite (Cal) and portlandite (Port) can be attributed to dissolution and subsequent mineral neo-formation of gypsum (Gp), anhydrite (Anh) and bassanite (Bs) formation, which causes intense microstructural damage of the concrete. X-ray amorphous phases (Amph), mainly represent the $\mathrm{CSH}$ phases of the cement. 
Table Captions:

Table 1: Wastewater chemistry along the flow direction within the sewer system. Samples were gathered from the two storage basins (SB1 and SB2) as well as from the first (GS1-1), 6th (GS1-6-6) and 7th manhole of gravity sewer 1 (GS1-7-2), and from the first manhole of gravity sewer 2 (GS2-16). Temperature $\left(\mathrm{T}^{\circ} \mathrm{C}\right), \mathrm{pH}$, electric conductivity $(\mathrm{EC})$ and redox potential $(\mathrm{Eh})$ were measured directly after sampling. Additionally, concentrations of dissolved organic carbon (DOC) are displayed. Complete concentrations of cations $\left(\mathrm{Na}^{+}, \mathrm{NH}_{4}^{+}, \mathrm{K}^{+}\right)$and anions $\left(\mathrm{Cl}^{-}, \mathrm{PO}_{4}{ }^{3-}\right)$ are displayed within the Appendix.

Table 2: Characteristics of drill cores taken from heavily damaged concrete manholes $\left(\mathrm{N}_{\mathrm{dc}}=\right.$ number of cores extracted) showing various states of concrete corrosion. The residual thickness $\left(L_{d c}\right)$ of each altered concrete liner was directly measured and compared with that of unaltered concrete $(13.0 \mathrm{~cm})$ to achieve corrosion rates in $\mathrm{cm} \mathrm{yr}^{-1}\left(\mathrm{R}_{\mathrm{c}}\right)$ and the loss of material $(\mathrm{ML})$. The depth of the different manholes (shaft depth), the compression strength (CS) and density $\left(\rho_{\text {concrete }}\right)$ of the drill cores extracted is additionally reported.

Table 3: Mineralogical composition of concrete samples of non-corroded concrete from drill cores, as well as of corroded areas obtained by Rietveld refinement of powder XRD patterns in wt. \%, containing quartz $(\mathrm{Qz})$, plagioclase (PI), alkali feldspar (Kfs), calcite (Cal), muscovite (Ms), portlandite (Port), hornblende $(\mathrm{Hbl})$, clinochlore $(\mathrm{Clc})$, gypsum $(\mathrm{Gp})$, bassanite $(\mathrm{Bs})$, anhydrite $(\mathrm{Anh})$, and x-ray amorphous phases (Amph).

Table 4: Chemical composition of expressed interstitial solutions (PF) from strongly deteriorated concrete of GS1 and GS2. The $\mathrm{pH}$ and electrical conductivity $(\mathrm{EC})$ were measured under laboratory conditions at $23^{\circ} \mathrm{C}$. Saturation indices (SI) for gypsum (Gp), bassanite (Bs) and anhydrite (Anh) were calculated using the computer code PHREEQC. The ion mass balance error (in \%) is reported. 
Appendix A1: Chemical composition of wastewater samples taken from different manholes within GS1 and GS2 as well as from SB1 and SB2. DOC: total dissolved organic carbon, where values are referred to wt. \% of C. 


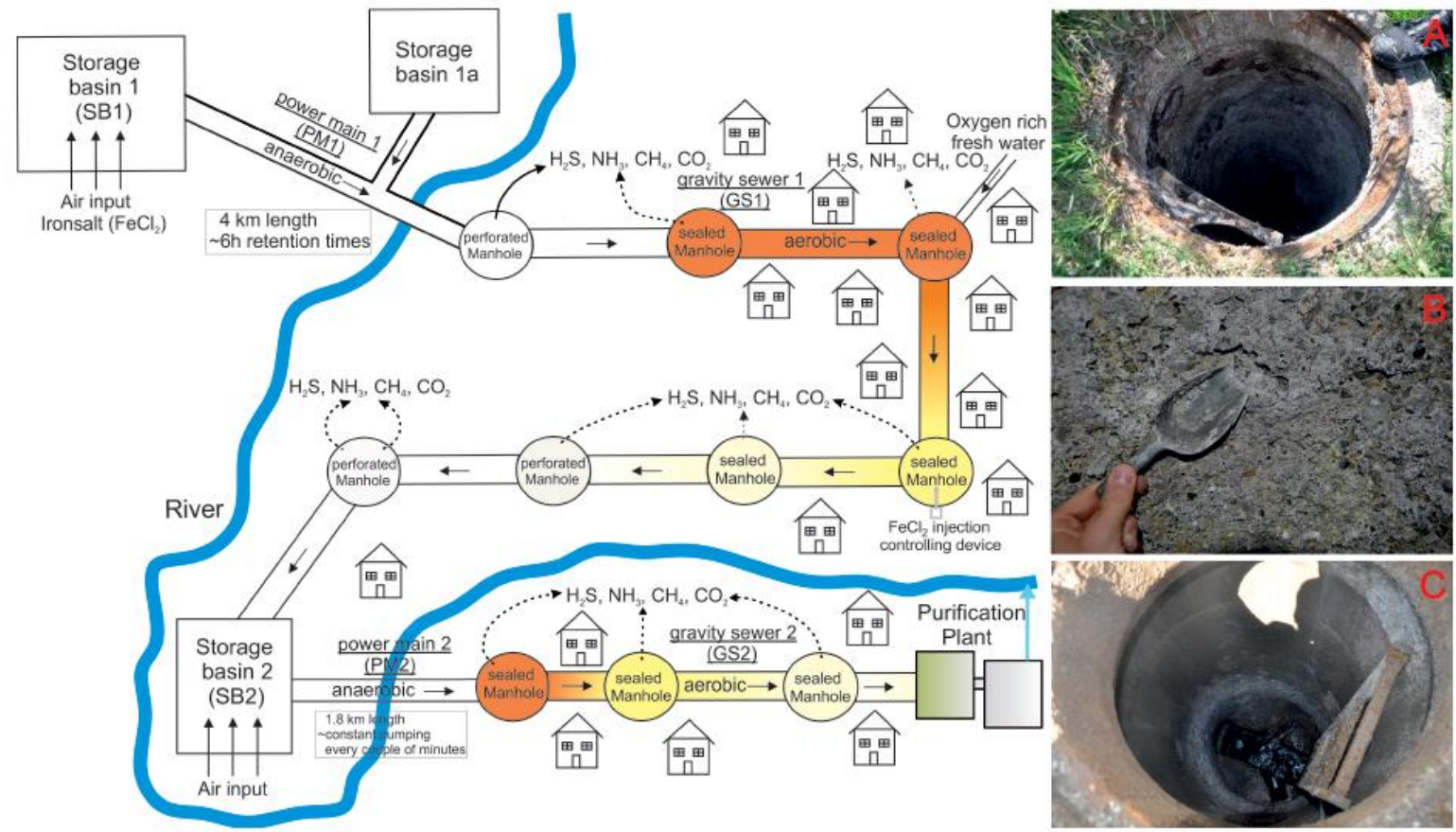

Figure 1 


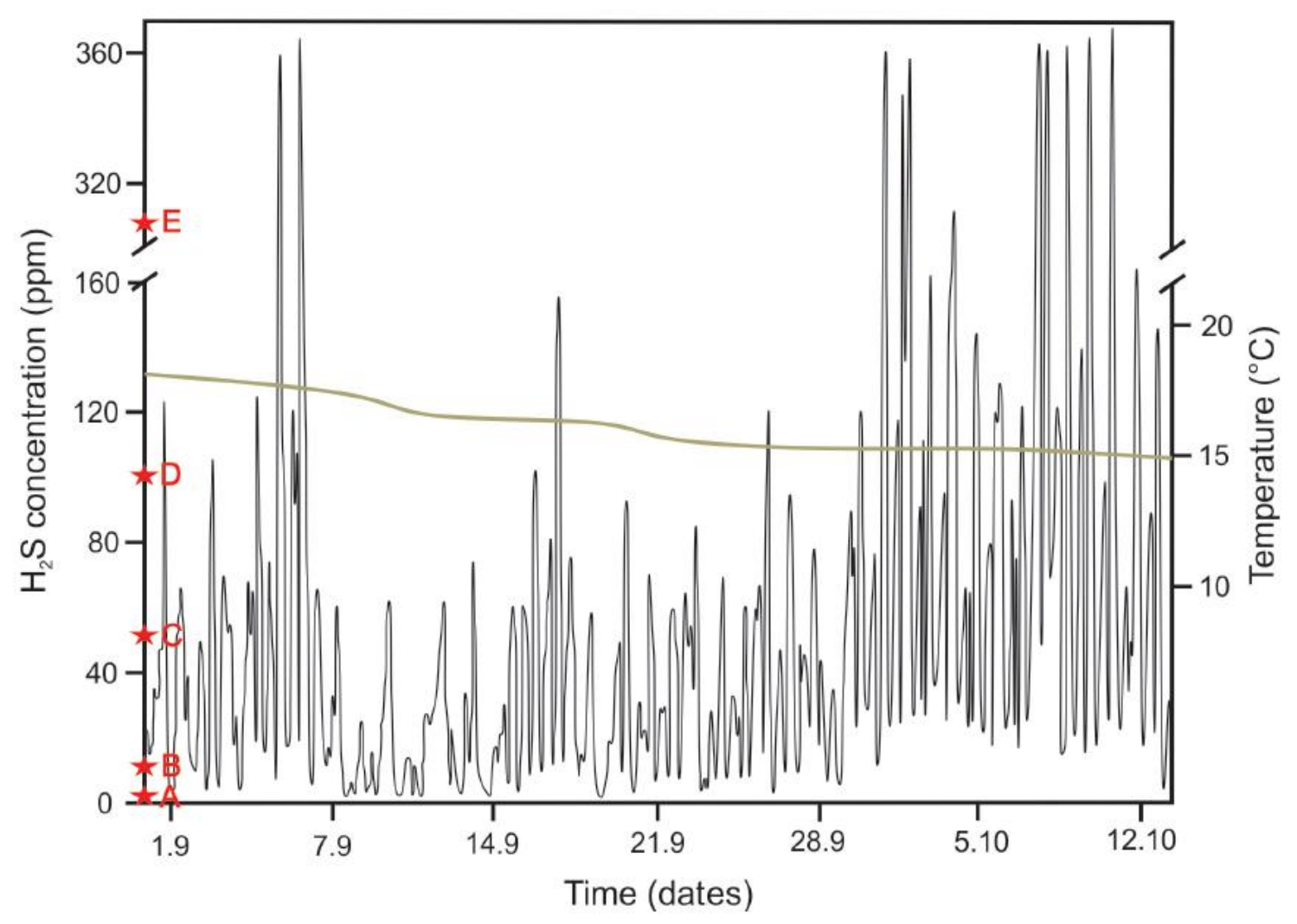

Figure 2 

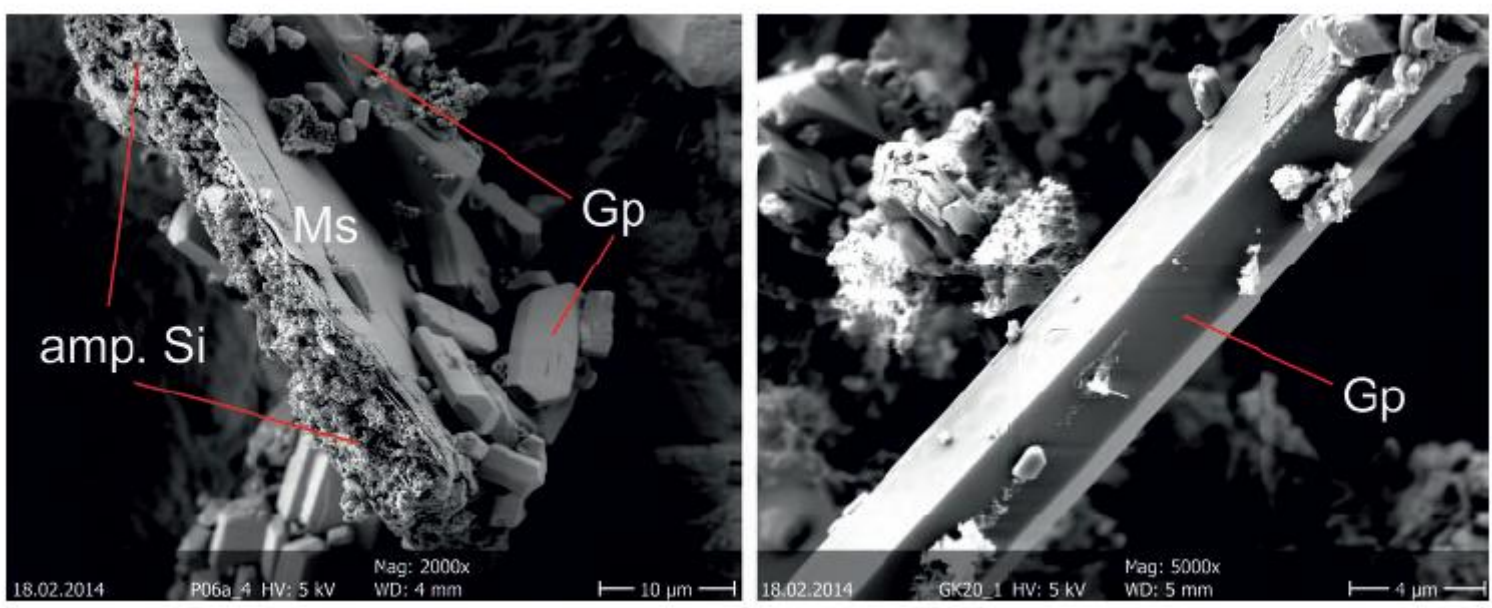

Figure 3 


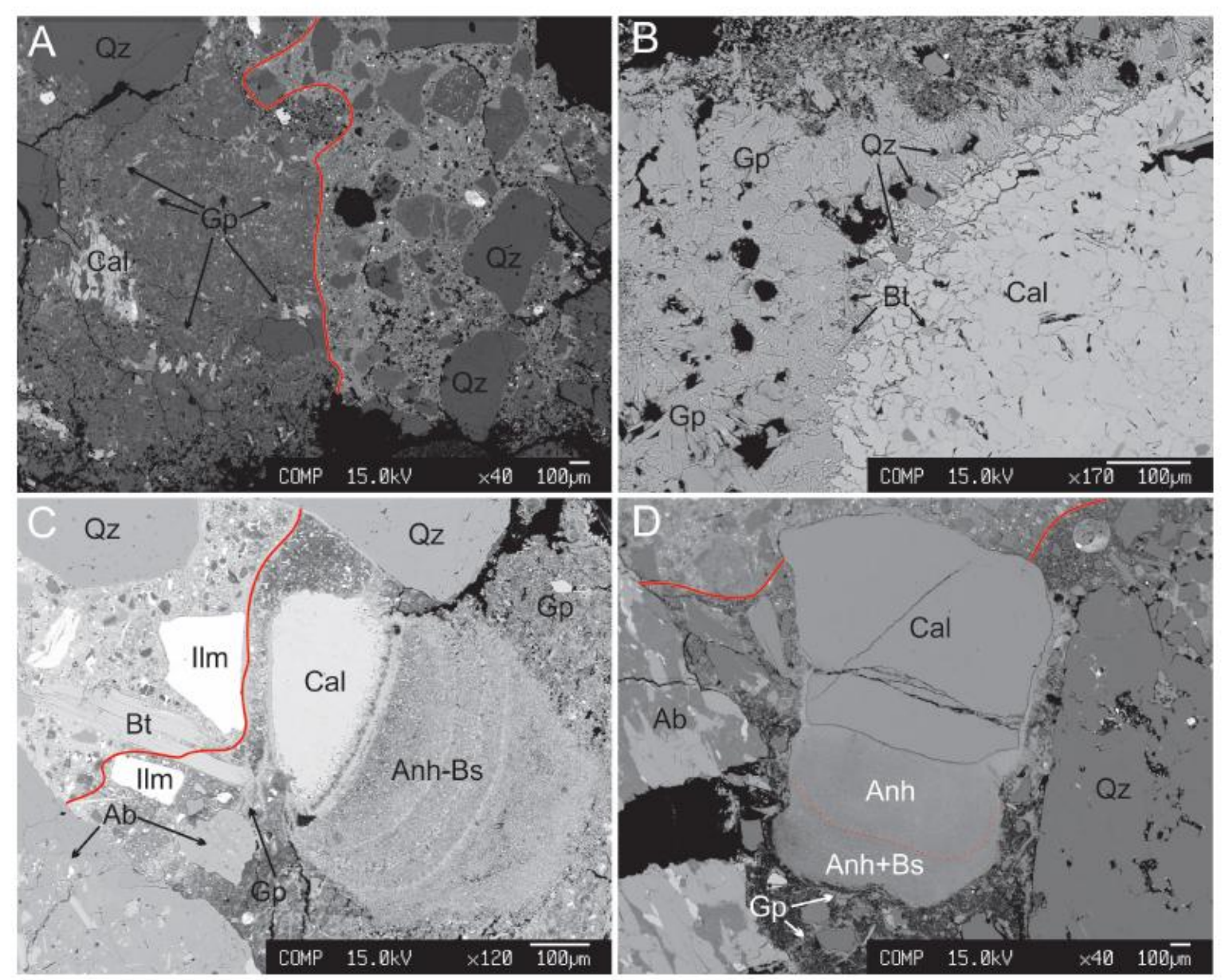

Figure 4 


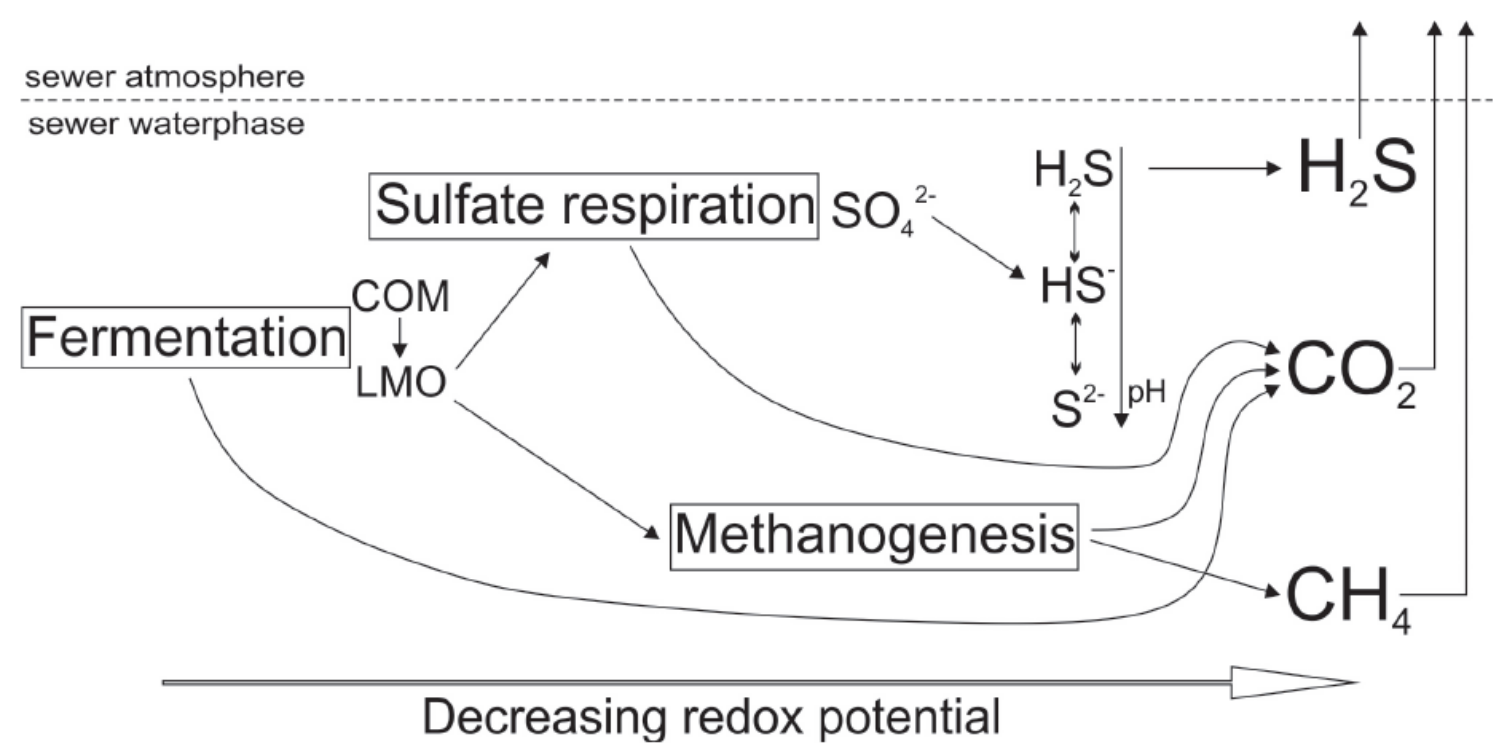

Figure 5 


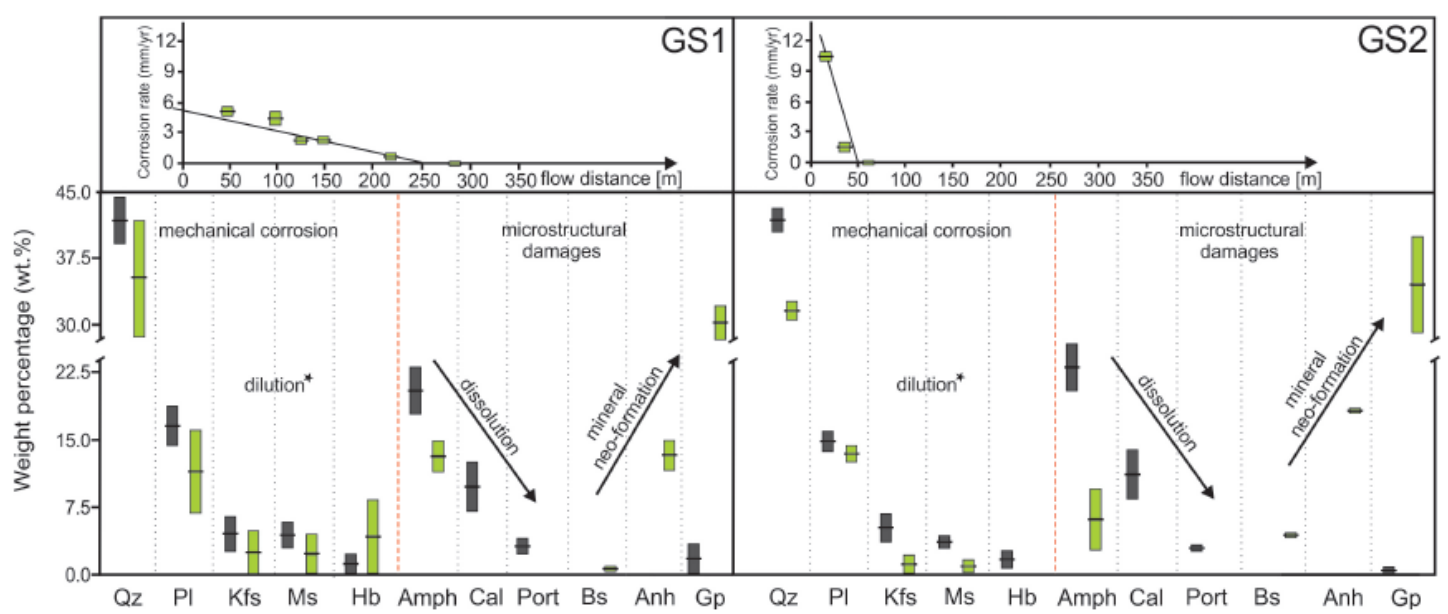

Figure 6 
Table 1:

\begin{tabular}{|c|c|c|c|c|c|c|c|c|c|}
\hline Sample ID & $\mathrm{pH}$ & $\begin{array}{l}\mathrm{T} \\
{ }^{\circ} \mathrm{C}\end{array}$ & $\begin{array}{c}\mathrm{EC} \\
\mathrm{mS} \mathrm{cm}^{-1}\end{array}$ & $\begin{array}{l}\text { Eh } \\
\mathrm{mV}\end{array}$ & $\begin{array}{c}\mathrm{O}_{2} \\
\mathrm{mg} \mathrm{l}^{-1}\end{array}$ & $\begin{array}{l}\mathrm{SO}_{4}{ }^{2-} \\
\mathrm{mg} \mathrm{I}^{-1}\end{array}$ & $\begin{array}{l}\mathrm{Ca}^{2+} \\
\mathrm{mgl}^{-1}\end{array}$ & $\begin{array}{l}\mathrm{Mg}^{2+} \\
\mathrm{mg} \mathrm{l}^{-1}\end{array}$ & $\begin{array}{l}\mathrm{DOC} \\
\mathrm{mg} \mathrm{I}^{-1}\end{array}$ \\
\hline SB1-5 & 8.2 & 10.0 & 1.7 & 51.0 & 0.8 & 74.3 & 65.2 & 13.9 & $\overline{73.0}$ \\
\hline GS1-1 & 7.4 & 8.0 & 1.7 & -157 & 1.4 & 41.2 & 74.6 & 14.9 & 64.5 \\
\hline GS1-6-5 & 7.4 & 17.7 & 1.4 & -209 & 1.6 & 23.3 & 66.9 & 12.2 & 56.2 \\
\hline GS1-7-2 & 7.3 & 9.1 & 1.5 & -248 & 1.8 & 152 & 114 & 13.2 & 83.0 \\
\hline SB2-2 & 7.8 & 9.6 & 1.8 & 32.0 & 4.3 & 249 & 147 & 14.3 & 83.0 \\
\hline GS2-1-6 & 7.6 & 13.5 & 0.9 & -320 & 0.5 & 28.7 & 49.3 & 9.90 & 27.5 \\
\hline
\end{tabular}


Table 2:

\begin{tabular}{|c|c|c|c|c|c|c|c|}
\hline Manhole ID & $\begin{array}{c}\text { shaft depth } \\
\mathrm{cm}\end{array}$ & $\begin{array}{c}\mathrm{CS} \\
\mathrm{N} / \mathrm{mm}^{2}\end{array}$ & $\begin{array}{l}\rho_{\text {concrete }} \\
\mathrm{kg} / \mathrm{m}^{3}\end{array}$ & $\mathrm{~N}_{\mathrm{dc}}$ & $\begin{array}{l}\mathrm{L}_{\mathrm{dc}} \\
\mathrm{cm}\end{array}$ & $\begin{array}{l}\mathrm{ML} \\
\mathrm{cm}\end{array}$ & $\begin{array}{c}\mathrm{R}_{\mathrm{c}} \\
\mathrm{cm} \mathrm{yr}^{-1}\end{array}$ \\
\hline$\overline{\text { GS1-4 }}$ & 290 & 85.1 & 2370 & 4 & $8.5 ; 9.5 ; 9.0 ; 10.0$ & $4.5 ; 3.5 ; 4.0 ; 3.0$ & $0.5 ; 0.4 ; 0.4 ; 0.3$ \\
\hline GS1-6 & 315 & 97.9 & 2410 & 2 & $9.0 ; 11.0$ & $4.0 ; 2.0$ & $0.4 ; 0.2$ \\
\hline GS1-7 & 273 & 70.5 & 2340 & 2 & $11.0 ; 11.5$ & $2.0 ; 1.5$ & $0.2 ; 0.2$ \\
\hline GS1-26 & 260 & 79.9 & 2330 & 2 & $10.0 ; 12.0$ & $3.0 ; 1.0$ & $0.3 ; 0.1$ \\
\hline GS1-29 & 220 & 90.0 & 2390 & 2 & $12.5 ; 12.5$ & $0.5 ; 0.5$ & $0.1 ; 0.1$ \\
\hline GS1-32 & 170 & 83.4 & 2310 & 2 & $12.0 ; 12.5$ & $1.0 ; 0.5$ & $0.1 ; 0.1$ \\
\hline GS2-1-2 & 264 & 106.2 & 2390 & 6 & $4.0 ; 5.0 ; 5.0 ; 6.5 ; 7.0 ; 9.5$ & $9.0 ; 8.0 ; 8.0 ; 6.5 ; 6.0 ; 3.5$ & $1.0 ; 0.9 ; 0.9 ; 0.7 ; 0.7 ; 0.4$ \\
\hline GS2-2 & 274 & 97.8 & 2380 & 1 & 11.0 & 2.0 & 0.2 \\
\hline
\end{tabular}


Table 3:

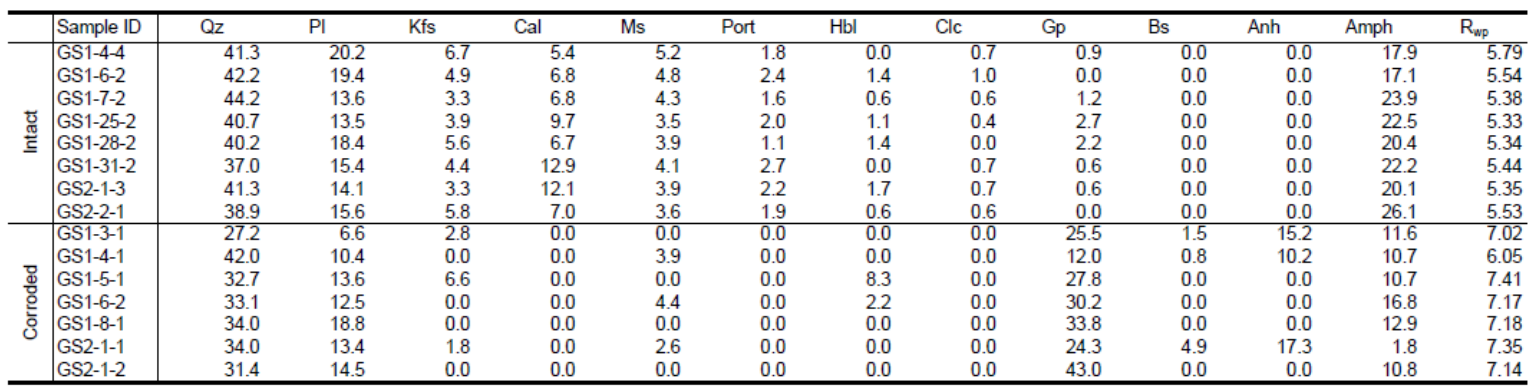


Table 4:

\begin{tabular}{|c|c|c|c|c|c|c|c|c|c|c|c|c|c|c|c|c|c|c|c|c|c|}
\hline e ID & $\mathrm{pH}$ & $\begin{array}{c}\mathrm{EC} \\
\mathrm{mS} \mathrm{cm}^{-1}\end{array}$ & $\begin{array}{l}\mathrm{Na}^{+} \\
\mathrm{mg} \mathrm{l}^{-1}\end{array}$ & $\begin{array}{l}\mathrm{NH}_{4}{ }^{+} \\
\mathrm{mg} \mathrm{l}^{-1}\end{array}$ & $\begin{array}{c}\mathrm{K}^{+} \\
\mathrm{mg} \mathrm{l}^{-1}\end{array}$ & $\mathrm{mg} \mathrm{l}^{-1}$ & $n$ & $\begin{array}{l}\mathrm{Sr}^{2} \\
\mathrm{mg}\end{array}$ & ${ }^{1} \mathrm{mg}$ & $\begin{array}{c}\mathrm{Fe} \\
\mathrm{mgl}^{-1}\end{array}$ & $\begin{array}{c}\mathrm{Zn} \\
\mathrm{mg} \mathrm{l}^{-1}\end{array}$ & $\begin{array}{c}\mathrm{Al}^{-1} \\
\mathrm{mg} \mathrm{l}^{-1}\end{array}$ & $\begin{array}{c}\mathrm{F}^{-} \\
\mathrm{mgl}^{-1}\end{array}$ & $\begin{array}{r}\mathrm{Cl}^{-} \\
\mathrm{mg}\end{array}$ & $\begin{array}{l}\mathrm{NO}_{3}^{-} \\
\mathrm{mg} \mathrm{l}^{-1}\end{array}$ & $\begin{array}{l}\mathrm{SO}_{4}{ }^{2-} \\
\mathrm{mg} \mathrm{I}^{-1}\end{array}$ & $\begin{array}{l}\mathrm{PO}_{4}{ }^{3-} \\
\mathrm{mgl}^{-1}\end{array}$ & $\begin{array}{l}\mathrm{SI} \\
\mathrm{Gp}\end{array}$ & $\begin{array}{l}\text { SI } \\
\text { Bs }\end{array}$ & $\begin{array}{c}\text { SI } \\
\text { Anh }\end{array}$ & \\
\hline GS1-3-PF1 & 0.9 & 59.5 & 97.8 & 296 & 122 & 2115 & 680 & 5.88 & 324.5 & 1527 & 4.22 & 311 & bdl. & 44.6 & 29.0 & 13605 & 198 & 0.11 & -0.84 & 0.10 & -2.51 \\
\hline GS14-PF1 & 0.9 & 64.2 & 91 & 152 & 266 & 243 & 584 & 5.69 & 930.2 & 2080 & 3.47 & 540 & bdl. & 168 & 15.0 & 18139 & 156 & 0.14 & -0.80 & 0.14 & -2.38 \\
\hline GS1-5-PF1 & 2.4 & 5.7 & 182 & 80.8 & 33.3 & $\begin{array}{l}3 \\
3\end{array}$ & 577 & 3.26 & 1.90 & 151 & 1.58 & 21.2 & bdl. & 120 & 8.75 & 2719 & 0.89 & 0.06 & -0.89 & 0.05 & 1.22 \\
\hline GS1-5-PF2 & 3.1 & 4.6 & 167 & 62.7 & 55.2 & 61.9 & 638 & 3.98 & 31.31 & 164 & 1.23 & 23 & bdl. & 112 & 11.7 & 2730 & 0.50 & 0.11 & -0.84 & 0.10 & -0.73 \\
\hline GS1-6-PF1 & 2.7 & 8.7 & 109 & 236 & 186 & 309 & 542 & 13.7 & 79.87 & 838 & 4.89 & 394 & 9.20 & 15.4 & 52.2 & 7127 & 3.74 & 0.10 & -0.85 & 0.09 & 3.84 \\
\hline GS & 1.6 & 20.4 & 103 & 315 & 163 & 206 & 621 & 15.0 & 17.6 & 1005 & 3.90 & 305 & 5.23 & 15.9 & 45.1 & 9951 & 17.02 & 0.15 & -0.80 & 0.14 & 0.95 \\
\hline PF3 & 2.3 & 11.3 & 100 & 341 & 194 & 343 & 508 & 8.10 & 43.0 & 1721 & 4.46 & 401 & 8.12 & 23.4 & 45.1 & 9436 & 15.08 & 0.10 & -0.85 & 0.09 & 1.04 \\
\hline PF4 & 1.6 & 18.3 & 75.4 & 370 & 111 & 126 & 494 & 3.54 & 412.4 & 643 & 1.61 & 139 & bdl. & 20.8 & 28.5 & 7750 & 7.19 & 0.04 & -0.91 & 0.03 & -0.64 \\
\hline 1-6-PF5 & 1.8 & 12.7 & 59.2 & 284 & 108 & 92.2 & 469 & 3.04 & 411.3 & 658 & 1.55 & 122 & bdl. & 17.0 & 22.4 & 6092 & 7.06 & 0.02 & -0.94 & 0.01 & -0.40 \\
\hline GS2-1-PF1 & 1.0 & 102.0 & 2978 & 2994 & 1383 & 4322 & 551 & 14.9 & $\begin{array}{l}9 \\
9\end{array}$ & 15693 & 152 & 5720 & 40.6 & 1648 & 6.58 & 104210 & 555 & 0.41 & -0.52 & 0.43 & 5.79 \\
\hline GS2-1-PF2 & 1.1 & 69.5 & 404 & 635 & 534 & 1521 & 575 & 6.53 & 365.7 & 6241 & 70 & 1675 & 20.0 & 316 & 1.99 & 44090 & 345 & 0.23 & -0.72 & 0.23 & -0.87 \\
\hline GS2 & 0.7 & 101.0 & 573 & 210 & 330 & 990 & 567 & 4.54 & 48.1 & 2818 & 23 & 998 & bdl. & 376 & 5.35 & 40818 & 161 & 0.11 & -0.83 & 0.11 & 2.16 \\
\hline GS2-1-PF4 & 0.9 & 66.4 & 523 & 198 & 346 & 931 & 520 & 8.47 & 759.6 & 2943 & 18 & 919 & bdl. & 380 & 3.85 & 32717 & 141 & 0.10 & -0.85 & 0.09 & -0.11 \\
\hline
\end{tabular}


AppendixA1:

\begin{tabular}{|c|c|c|c|c|c|c|c|c|c|}
\hline Sample ID & $\begin{array}{c}\mathrm{Na}^{+} \\
\mathrm{mg} \mathrm{l}^{-1}\end{array}$ & $\begin{array}{l}\mathrm{NH}_{4}^{+} \\
\mathrm{mg} \mathrm{l}^{-1}\end{array}$ & $\begin{array}{c}\mathrm{K}^{+} \\
\mathrm{mg} \mathrm{l}^{-1}\end{array}$ & $\begin{array}{l}\mathrm{Mg}^{2+} \\
\mathrm{mg} \mathrm{l}^{-1}\end{array}$ & $\begin{array}{l}\mathrm{Ca}^{2+} \\
\mathrm{mg} \mathrm{l}^{-1}\end{array}$ & $\begin{array}{c}\mathrm{Cl}^{-} \\
\mathrm{mg} \mathrm{l}^{-1}\end{array}$ & $\begin{array}{l}\mathrm{SO}_{4}{ }^{2-} \\
\mathrm{mg} \mathrm{l}^{-1}\end{array}$ & $\begin{array}{l}\mathrm{PO}_{4}{ }^{3-} \\
\mathrm{mg} \mathrm{l}^{-1}\end{array}$ & $\begin{array}{l}\mathrm{DOC} \\
\mathrm{mg} \mathrm{l}^{-1}\end{array}$ \\
\hline$\overline{\text { SB1-1 }}$ & 85.4 & 76.9 & 23.1 & 12.9 & 69.0 & 104 & 64.0 & 2.77 & n.a. \\
\hline SB1-4 & 72.9 & 85.4 & 21.4 & 13.0 & 83.7 & 90.4 & 115 & 0.45 & 61.1 \\
\hline SB1-5 & 142 & 104 & 24.9 & 13.9 & 65.2 & 237 & 74.3 & 1.84 & 73.0 \\
\hline GS1-1 & 136 & 73.3 & 25.9 & 14.9 & 74.6 & 228 & 41.2 & 6.34 & 64.5 \\
\hline GS1-6-1 & 39.6 & 23.5 & 8.62 & 4.76 & 27.3 & 46.3 & 14.3 & 3.88 & 82.5 \\
\hline GS1-6-2 & 37.3 & 22.7 & 8.26 & 4.86 & 38.0 & 43.8 & 41.4 & 3.97 & 59.4 \\
\hline GS1-6-3 & 28.6 & 41.3 & 9.55 & 7.91 & 27.7 & 25.9 & 21.5 & 8.02 & 56.2 \\
\hline GS1-6-4 & 93.4 & 56.8 & 25.2 & 11.2 & 71.5 & 102 & 40.9 & 7.80 & n.a. \\
\hline GS1-6-5 & 92.0 & 70.0 & 25.7 & 12.2 & 66.9 & 102 & 23.3 & 14.8 & n.a. \\
\hline GS1-6-6 & 68.6 & 50.4 & 18.3 & 10.1 & 79.4 & 87.3 & 79.7 & 8.13 & 50.2 \\
\hline GS1-6-7 & 67.9 & 50.0 & 18.0 & 9.75 & 70.5 & 86.4 & 51.0 & 9.43 & 48.0 \\
\hline GS1-6-8 & 70.8 & 58.6 & 18.4 & 10.8 & 73.0 & 94.3 & 57.2 & 7.23 & 46.2 \\
\hline GS1-6-9 & 138 & 74.9 & 23.9 & 15.2 & 73.6 & 223 & 48.8 & 5.32 & 65.0 \\
\hline GS1-7-1 & 95.5 & 70.9 & 23.6 & 13.2 & 81.5 & 89.7 & 64.4 & 18.6 & 83.7 \\
\hline GS1-7-2 & 95.9 & 70.3 & 24.3 & 13.2 & 114 & 91.0 & 152 & 16.8 & 83.0 \\
\hline GS1-8-1 & 27.9 & 28.2 & 9.21 & 6.71 & 26.3 & 29.9 & 15.4 & 4.03 & 52.4 \\
\hline SB2-1 & 34.8 & 23.5 & 8.18 & 4.82 & 30.3 & 40.2 & 23.3 & 3.55 & 38.7 \\
\hline SB2-2 & 110 & 83.9 & 32.9 & 14.3 & 147.5 & 104 & 249 & 15.3 & 83.0 \\
\hline GS2-1-1 & 36.3 & 25.3 & 8.38 & 5.18 & 28.2 & 43.5 & 13.8 & 5.09 & 56.5 \\
\hline GS2-1-2 & 77.9 & 68.3 & 24.1 & 17.0 & 77.4 & 85.2 & 45.0 & 10.5 & n.a. \\
\hline GS2-1-5 & 60.9 & 51.1 & 20.8 & 10.1 & 49.9 & 64.1 & 30.8 & 11.3 & 25.5 \\
\hline GS2-1-6 & 59.5 & 49.9 & 20.1 & 9.87 & 49.3 & 62.8 & 28.7 & 11.2 & 27.5 \\
\hline GS2-1-7 & 94.9 & 70.9 & 21.0 & 13.2 & 76.2 & 89.1 & 44.4 & 19.0 & 73.2 \\
\hline GS2-1-8 & 94.0 & 71.6 & 21.2 & 13.0 & 69.7 & 88.6 & 23.8 & 19.4 & 77.3 \\
\hline GS2-1-9 & 152 & 77.4 & 22.6 & 14.3 & 63.8 & 214 & 32.0 & 11.1 & 69.2 \\
\hline
\end{tabular}

n.a. =not analyzed 